\title{
Evaluation of TGF $\beta 1$, IL-8 and Nitric Oxide in the Serum of Diffuse Axonal Injury Patients and Its Association with Clinical Status and Outcome
}

\author{
Difüz Aksonal Yaralanma Hastalarının Serumunda TGF $\beta 1, I L-8$ ve \\ Nitrik Oksit Değerlendirilmesi ve Klinik Durum ve Sonuç ile İlişsileri
}

\author{
Seyed Mojtaba SOHREVARDI ${ }^{1}$, Mehdi AHMADINEJAD ${ }^{2}$, Karamuzian SAID ${ }^{3}$, Farhad SARAFZADEH ${ }^{4}$, \\ Somayeh Soleimani ZADEH ${ }^{4}$, Mohammad YOUSEFI $^{4}$, Omid SAVARI ${ }^{4}$ \\ ${ }^{1}$ Neuroscience Research Center and Faculty of Pharmacy, Kerman University of Medical Sciences, Department of Neurosurgery, \\ Kerman, Islamic Republic of Iran \\ ${ }_{2}^{2}$ Physiology Research Center and Faculty of Medicine, Kerman University of Medical Sciences, Department of Neurosurgery, \\ Kerman, Islamic Republic of Iran \\ ${ }^{3}$ Kerman University of Medical Sciences, Department of Neurosurgery, Kerman, Islamic Republic of Iran \\ ${ }^{4}$ Kerman University of Medical Sciences, Faculty of Medicine, Department of Neurosurgery, Kerman, Islamic Republic of Iran
}

Correspondence address: Seyed Mojtaba SOHREVARDI / E-mail: Mehdia50@gmail.com

\begin{abstract}
AIM: The aim was to evaluate the level of interleukin 8 (IL-8), transforming growth factor $\beta 1$ (TGF $\beta 1$ ) and Nitric oxide (NO) in diffuse axonal injury (DAI) and its association to the outcome and clinical status.

MATERIAL and METHODS: This cross-sectional study was conducted on 20 patients with DAI and 20 patients with multiple traumas without head injury and 20 healthy subjects as controls. Blood levels of IL-8, TGF $\beta 1$ and nitric oxide in the 1 st, 2 nd, 3rd and 7th days of injury were measured. Glasgow coma scale (GCS) of patients was recorded. The patients' outcome was evaluated by Glasgow Outcome Scale (GOS).

RESULTS: The level of TGF $\beta 1$ was increasing during the admission and had the maximum level at the 7th day. In the DAI group, there was significant correlation between GOS score and serum IL-8 at 7 th day of admission $(r=-0.68, p=0.002)$. In this group the GCS was found to be significantly correlated with the IL-8 concentration at 7 th day of admission $(p=0.026, r=-0.55)$.

CONCLUSION: IL-8 has negative correlation with GCS and GOS. TGF $\beta 1$ could protect the brain from cytotoxics, hypoxia and acidosis so its level comes down in brain injuries as a result of its overuse.
\end{abstract}

KEYWORDS: Diffuse axonal injury, NO, IL-8, TGF $\beta 1$

ÖZ

AMAÇ: Burada amaç difüz aksonal yaralanmada (DAY) interlökin 8 (IL-8), transforme edici büyüme faktörü $\beta 1$ (TGF $\beta 1$ ) ve Nitrik oksit (NO) düzeyini ve sonuç ve klinik durumla ilişkisini değerlendirmekti.

YÖNTEM ve GEREÇLER: Bu çapraz kesitsel çalışma, 20 DAY hastasında, 20 kafa yaralanması olmadan çoklu travma hastasında ve kontrol olarak 20 sağlıklı kişide gerçekleştirildi. Yaralanmadan 1, 2, 3 ve 7 gün sonra kanda IL-8, TGF $\beta 1$ ve nitrik oksit düzeyleri ölçüldü. Hastaların Glasgow koma ölçeği (GCS) değerleri kaydedildi. Hastaların sonucu Glasgow Sonuç Ölçeği (GOS) ile değerlendirildi.

BULGULAR: TGF $\beta 1$ düzeyi hastaneye yatışla birlikte artıyordu ve maksimum düzeye 7. günde ulaştı. DAY grubunda GOS skoru ile yattıktan sonraki 7. gün serum IL-8 değeri arasında anlamlı bir korelasyon vardı $(r=-0,68, p=0,002)$. Bu grupta GCS'nin yattıktan sonra 7. günde IL-8 konsantrasyonuyla önemli ölçüde korelasyon gösterdiği bulundu $(p=0,026, r=-0,55)$.

SONUÇ: IL-8'in GCS ve GOS ile negatif korelasyonu vardır. TGF $\beta 1$ beyni sitotoksik maddeler, hipoksi ve asidozdan koruyabilir ve bu nedenle beyin yaralanmalarında fazla kullanılmasıyla düzeyi düşer.

ANAHTAR SÖZCÜKLER: Difüz aksonal yaralanma, NO, IL-8, TGF $\beta 1$ 


\section{INTRODUCTION}

Neurodegeneration is a clinical statement in which the neurons degenerate and die after a severe sudden insult to the brain. This could happen after some acute insults including stroke, subarachnoid hemorrhage, head injury and other cerebrovascular accidents (CVA) (15).

Inflammatory processes have been shown as effective factor in the degeneration and acute injury-induced inflammation causing neurodegeneration $(1,3)$. An increase in the level of interleukin (IL) 8, IL-6, IL-10 and peripheral monocytes count after intracranial hemorrhage and traumatic brain injury shows the effect of these inflammatory mediators in the degeneration process and secondary insult. These mediators also have effect on multiple organ dysfunctions after severe brain injury $(5,11,13,14)$. In addition to these inflammatory degenerative factors, increased release of growth factors, neurotrophins and anti-inflammatory mediators including transforming growth factor $\beta 1$ (TGF $\beta 1$ ) and IL-10 protects the neurons against the excitotoxicities, acidosis, hypoxia and peroxidants after acute brain injuries (12).

There are few investigations about the clinical state and outcome of these patients and their association to the blood and CSF level of protective and degenerative mediators. This study was designed to evaluate the level of IL-8, TGF $\beta 1$ and nitric oxide (NO) in diffuse axonal injury (DAI) and its association to the outcome and disease severity.

\section{MATERIAL and METHODS}

This study was a prospective study on 20 patients with diffuse axonal injury in the neurosurgery department of Bahonar hospital, Kerman, Iran from March to December 2010.

Inclusion criteria were male sex, age over 18, admission to the hospital within 24 hours of the injury and Glasgow Coma Scale (GCS) less than 10. Patients with infectious disease, myocardial infarction, autoimmune, kidney and liver disease and multiple trauma were not enrolled to the study.

As control groups, 20 patients with multiple trauma without head injury (MT), and 20 healthy subjects were enrolled in the study.

\section{Evaluation}

The patients and controls were evaluated for blood levels of IL-8, TGF $\beta 1$ and nitric oxide (NO) in the $1^{\text {st }}, 2^{\text {nd }}, 3^{\text {rd }}$ and $7^{\text {th }}$ days after injury. The blood samples were centrifuged and the serum was collected and kept at $-70^{\circ} \mathrm{C}$ until assessment. The concentration of IL- 8 and TGF $\beta 1$ was measured using enzyme linked immunosorbent assay (ELIZA) method with Biosource Europe Belgium and DRG instruments $\mathrm{GmbH}$ Germany kits, respectively, and the NO level was measured using Griess method with Molecular Probes Europe company kit (Netherlands). The body temperature, platelet and leukocyte count and GCS of patients were recorded in every evaluation. The patients' outcome was evaluated on the discharge day by Glasgow Outcome Scale (GOS).

\section{Ethics}

The study protocol was approved by ethic committee of Kerman University of Medical Sciences. Informed written consent was obtained from all patients' next of kin after detailed explanation.

\section{Statistical Analyses}

The comparison between two groups was done using student t-test. For evaluation of trend of changes in factors during admission, multiple measurement ANOVA analysis was carried out, the association of the factor levels and the outcome was evaluated using Pearson correlation. All analyses were performed using SPSS v16.

\section{RESULTS}

There were 20 men with DAI and 20 MT and 20 healthy men in this study. The mean age of DAl group was 33.6 \pm 12.6 years which had no significant difference with MT $(36.8 \pm 18.13)$ and healthy groups $(25.45 \pm 4.68)$.

In DAI group, mean GCS at first day of injury was $7 \pm 1.29$. Mean GCS in patients with DAl increased in $2^{\text {nd }}, 3^{\text {rd }}$, and $7^{\text {th }}$ days after injury to $7.85 \pm 1.81,8.7 \pm 2.55$ and $11.7 \pm 3.75$, respectively. Mean GOS in the study group (DAl) was $4.6 \pm 0.68$.

\section{IL-8}

The blood level of IL-8 was $76.22 \pm 31.34$ at the first day and it decreased to $70.13 \pm 37$ at $2^{\text {nd }}, 66.02 \pm 33.36$ at $3^{\text {rd }}$ and $49.07 \pm 23.54$ at $7^{\text {th }}$ day of admission in the DAl group. The level of IL-8 showed increase from $1^{\text {st }}$ to $2^{\text {nd }}$ day of admission in the MT group but it began to decrease after the $2^{\text {nd }}$ day to the least level at the $7^{\text {th }}$ day (Table I). The mean level of IL-8 in 4 measurements in DAl group was higher than the healthy group $(65.3 \pm 11.6$ vs. $21.54 \pm 5.16, p=0.44)$ but less than MT group $(65.3 \pm 11.6$ vs. $279 \pm 124.5, p=0.014)$.

\section{TGF $\beta 1$}

The level of TGF $\beta 1$ was increasing during the admission and had the maximum level at the $7^{\text {th }}$ day (Table I). The mean level of TGF $\beta 1$ in the DAl group was significantly lower than the healthy group (117.8 \pm 9.4 vs. $215.1 \pm 44.9, p=0.003)$ but it did not have significant difference with MT group (117.8 \pm 9.4 vs. 127.5 $\pm 43.7, p=0.67)$.

\section{NO}

The serum level of NO metabolites had the highest level at the first day and it was decreasing during the admission to the lowest level at the $7^{\text {th }}$ day of admission in the DAl group. The NO concentration in the DAI group was significantly higher than the healthy group ( $37.9 \pm 3.4$ vs. $25.2 \pm 3.37, p=0.43$ ) but lower than MT group ( $37.9 \pm 3.4$ vs. $49.5 \pm 7.3, p=0.28)$.

\section{Correlation}

In the DAl group, there was significant correlation between GOS score and serum IL- 8 at $7^{\text {th }}$ day of admission ( $r=-0.68, p=$ 0.002 ). This correlation was not significant in the other days. In this group the GCS was found to be significantly correlated 
Table I: Blood Level of NO and TGF $\beta 1$ and WBC Count in Subjects (mean \pm SD)

\begin{tabular}{|c|c|c|c|c|}
\hline Variable & Day & DAl group $(n=20)$ & MT group $(n=20)$ & Healthy group $(n=20)$ \\
\hline \multirow{4}{*}{ IL-8 (pg/ml) } & $1^{\text {st }}$ & $76.22 \pm 31.34$ & $332.65 \pm 394.53$ & $21.54 \pm 5.16$ \\
\hline & $2^{\text {nd }}$ & $70.13 \pm 37$ & $384.72 \pm 401.65$ & - \\
\hline & $3^{\text {rd }}$ & $66.02 \pm 33.36$ & $298.32 \pm 252.64$ & - \\
\hline & $7^{\text {th }}$ & $49.07 \pm 23.54$ & $99.82 \pm 70.08$ & - \\
\hline \multirow{4}{*}{$\mathrm{NO}(\mu \mathrm{g} / \mathrm{ml})$} & $1^{\text {st }}$ & $40.23 \pm 9.26$ & $47.63 \pm 9.7$ & $25.2 \pm 3.37$ \\
\hline & $2^{\text {nd }}$ & $40.07 \pm 9.17$ & $54.39 \pm 9.29$ & - \\
\hline & $3^{\text {rd }}$ & $38.55 \pm 10.04$ & $56.1 \pm 7.29$ & - \\
\hline & $7^{\text {th }}$ & $33.07 \pm 8.63$ & $40.9 \pm 6.26$ & - \\
\hline \multirow{4}{*}{ TGF $\beta 1$ (pg/ml) } & $1^{\text {st }}$ & $109.18 \pm 34.12$ & $110.69 \pm 37.59$ & $215.11 \pm 44.85$ \\
\hline & $2^{\text {nd }}$ & $114.27 \pm 33.71$ & $90.67 \pm 43.37$ & - \\
\hline & $3^{\text {rd }}$ & $116.85 \pm 35.97$ & $117.37 \pm 61.12$ & - \\
\hline & $7^{\text {th }}$ & $130.99 \pm 38.09$ & $191.07 \pm 49.77$ & - \\
\hline
\end{tabular}

Note; IL-8, interleukin 8; NO, nitric oxide; TGF $\boldsymbol{\beta}$ 1, transforming growth factor $\beta$ 1.

with the IL-8 concentration at $7^{\text {th }}$ day of admission $(p=0.026$, $r=-0.55$ ) but not in the other days. The IL-8 level had significant relation to WBC count at $7^{\text {th }}$ day of admission $(p=0.002, r=$ 0.71 ), this relation was not significant in the other days. There was no significant correlation between platelet count and IL-8 level. Also the association of IL- 8 and the age of patients were not statistically significant.

In the DAI group, there was no significant correlation between TGF $\beta 1$ at $1^{\text {st }}, 2^{\text {nd }}, 3^{\text {rd }}$ and $7^{\text {th }}$ day and GOS and GCS. The TGF $\beta 1$ did not have significant association with WBC and platelet count and the patients' age. The correlation of NO with GOS and GCS was not statistically significant within this group. The serum NO level did not have association with WBC and platelet count and the patients' age.

\section{DISCUSSION}

There are many studies that show increased cytokine release in acute ischemic stroke, intracerebral hemorrhage and traumatic brain injury in the CNS and systemic flow $(5,11,13)$.

IL-8 is a potent chemoattractant that could activate PMN and elongate its half-life in vivo (11). Polymorphonuclear leukocyte (PMN) infiltration has been shown in association with the disability after ischemic cerebrovascular attack (1). Therefore the IL-8 activate and elongate the effect of PMNs in the inflammation-induced brain disability process. Based on the results of the present study, the level of IL- 8 has significant positive correlation with the WBC count at the $7^{\text {th }}$ day of admission in the DAI patients. This finding may confirm the mentioned effect of IL-8 in the PMN activation and number. However, this correlation could be an accidental finding considering loss or the association of IL-8 and WBC count in the previous days and in the MT group. In a study on acute stroke patients the level of IL- 6 and WBC count increased significantly. The level of TGF $\beta 1$ and IL- 6 did not have correlation with WBC count in that study (10).
The IL-8 level of the MT patients was found to be significantly higher than DAl patients in the present study whereas the IL-8 level in the DAl group was not different with healthy group. These findings could be due to the source of IL- 8 in the body that is mainly peripheral organs.

The level of IL- 6 in the cerebrospinal fluid has been reported to be related to the lesion extension in the ischemic stroke (17). The serum concentration of IL- 6 and IL- 8 has been shown to be associated with disease severity and patients' GCS in traumatic brain injury (7). There is no report of this association in DAI patients. We found that there is no correlation between the patients GCS and GOS with the inflammatory mediators (IL-8).

It has been shown that hypothermia induces antiinflammatory cytokine profile. Hypothermia has various effects on inflammatory cytokines, depending on site, time of measurement, and the presence of infection $(4,19)$. Previous studies have reported increased levels of IL-6 and IL-8 in cerebrospinal fluid of hypothermic pediatric traumatic brain injury and patients with cardiac arrest compared with normothermic patients $(2,6)$. This was not confirmed in DAI patients in our study.

The IL-8 level had association with the GOS and GCS at $7^{\text {th }}$ day of admission and higher IL-8 caused lower GOS score. In a study by Kostulas et. al. administration of antibody against IL-8 in cerebral perfusion injured rabbits was shown to protect the brain from polymorphonuclear infiltration and reduces the brain edema within 6 hours and infarction within 12 hours (11). Considering the results of the present study and the conclusion of the previous studies, IL-8 has important exacerbating effect on the brain lesion and its level could predict the outcome and clinical status of patients.

TGF $\beta 1$ could protect the brain from cytotoxics, hypoxia and acidosis so its level comes down in brain injuries as a result of its overuse. Significant difference of TGF $\beta 1$ between DAI 
and MT group in one hand and control healthy group in the other hand confirmed this theory. In a study by Slevin et. al. patients with ischemic stroke had significantly lower level of TGF $\beta 1$ in comparison to healthy group (16). TGF $\beta 1$ had no significant association with the platelet and WBC count that is due to different type of cells releasing this factor.

NO begins to elevate in the ischemic stroke patients by IL-1 mediating rule which is released to CSF and blood soon after the attack (17). In the traumatic brain injury, the NO level of CSF and extracellular fluid has been found to elevate within the first day after injury and then decreases gradually within the next 5 days $(8,9)$. The results of the present study showed that NO level increased in the first day after injury and began to decrease until $7^{\text {th }}$ day of admission. This finding was similar to the previous studies. NO concentration has been shown to be correlated with the GCS and GOS in some investigations that are in contrast to the results of the present study $(8,9,18)$. This controversy may be due to different way of sampling. They measured the NO level in the CSF but we evaluated its serum level.

\section{ACKNOWLEDGMENT}

We would like to express our sincere gratitude to Farzan Institute for Research \& Technology for technical assistance.

\section{REFERENCES}

1. Barone FC, Feuerstein GZ: Inflammatory mediators and stroke: New opportunities for novel therapeutics. J Cereb Blood Flow Metab19: 819-834, 1999

2. Buttram SDW, Wisnewski SR, Jackson EK, Adelson PD, Feldman K, Bayir H, Berger RP, Clark RSB, Kochanek PM: Multiplex assessment of cytokine and chemokine levels in cerebrospinal fluid flowing severe pediatric traumatic brain injury: Effects of moderate hypothermia. J Neurotrauma 24:1707-1717, 2007

3. Csuka E, Morganti-Kossmann MC, Lenzlinger PM, Joller $H$, Trentz O, Kossmann T: IL-10 levels in cerebrospinal fluid and serum of patients with severe traumatic brain injury: Relationship to IL-6, TNF-alpha, TGF-beta1 and blood-brain barrier function. J Neuroimmunol 101: 211-221, 1999

4. Diestel A, Roessler J, Berger F, Schmitt KRL: Hypothermia down regulates inflammation but enhances IL- 6 secretion by stimulated endothelial cells. Cryobiology 57:216-222, 2008

5. Dziedzic T, Bartus S, Klimkowicz A, Motyl M, Slowik A, Szczudlik A: Intracerebral hemorrhage triggers interleukin-6 and interleukin-10 release in blood. Stroke 33:2334-2335, 2002

6. Fries M, Stoppe C, Brucken D, Rossaint R, Kuhlen R: Influence of mild therapeutic hypothermia on the inflammatory response after successful resuscitation from cardiac arrest. J Crit Care 24:453-457, 2009
7. He LM, Qiu BH, Qi ST, Fang LX, Liu XJ: Dynamic changes of serum interleukin- 6 and interleukin- 8 in patients with acute traumatic brain injury and the clinical significance. Nan Fang Yi Ke Da Xue Xue Bao 29: 999-1001, 2009

8. Hlatky R, Furuya Y, Valadka AB, Goodman JC, Robertson CS: Microdialysate nitrate/nitrite levels following severe head injury. Acta Neurochir Suppl 81:331-333, 2002

9. Hlatky R, Goodman JC, Valadka AB, Robertson CS: Role of nitric oxide in cerebral blood flow abnormalities after traumatic brain injury. J Cereb Blood Flow Metab 23:582-588, 2003

10. Kim JS, Yoon SS, Kim YH, Ryu JS: Serial measurement of interleukin-6, transforming growth factor-beta, and S-100 protein in patients with acute stroke. Stroke 27:1553-1557, 1996

11. Kostulas N, Pelidou SH, Kivisakk P, Kostulas V, Link H: Increased IL-1 beta, IL-8, and IL-17 mRNA expression in blood mononuclear cells observed in a prospective ischemic stroke study. Stroke 30:2174-2179, 1999

12. Logan A, Frautschy SA, Gonzalez AM, Sporn MB, Baird A: Enhanced expression of transforming growth factor beta 1 in the rat brain after a localized cerebral injury. Brain Res 587: 216-225, 1992

13. Maier B, Schwerdtfeger K, Mautes A, Holanda M, Muller M, Steudel WI, Marzi I: Differential release of interleukines 6, 8, and 10 in cerebrospinal fluid and plasma after traumatic brain injury. Shock 15:421-426, 2001

14. Morganti-Kossmann MC, Hans VH, Lenzlinger PM, Dubs R, Ludwig E, Trentz O, Kossmann T: TGF-beta is elevated in the CSF of patients with severe traumatic brain injuries and parallels blood-brain barrier function. J Neurotrauma 16: 617-628, 1999

15. Perry VH, Bell MD, Brown HC, Matyszak MK: Inflammation in the nervous system. Curr Opin Neurobiol 5:636-641, 1995

16 Slevin M, Krupinski J, Slowik A, Kumar P, Szczudlik A, Gaffney $\mathrm{J}$ : Serial measurement of vascular endothelial growth factor and transforming growth factor-beta1 in serum of patients with acute ischemic stroke. Stroke 31:1863-1870, 2000

17. Tarkowski E, Ringqvist A, Rosengren L, Jensen C, Ekholm $S$, Wennmalm A: Intrathecal release of nitric oxide and its relation to final brain damage in patients with stroke. Cerebrovasc Dis 10:200-206, 2000

18. Tarkowski E, Rosengren L, Blomstrand C, Jensen C, Ekholm $\mathrm{S}$, Tarkowski A: Intrathecal expression of proteins regulating apoptosis in acute stroke. Stroke 30: 321-327, 1999

19. Xiong $M$, Yang $Y$, Chen GQ, Zhou WH: Post-ischemic hypothermia for $24 \mathrm{~h}$ in $\mathrm{P} 7$ rats rescues hippocampal neuron: Association with decreased astrocytes activation and inflammatory cytokine expression. Brain Res Bull 79:351-357, 2009 